Supporting Information

\title{
Fragment hit discovery and binding site characterization by indirect affinity capillary electrophoresis: application to factor XIla
}

Clara Davoine ${ }^{a, b}$, Alissia Pardo ${ }^{b}$, Lionel Pochet ${ }^{a, \neq}$, Marianne Fillet ${ }^{b, \ddagger,}$,

aNamur Medicine \& Drug Innovation Center (NAMEDIC - NARILIS), University of Namur, Rue de Bruxelles 61, 5000 Namur, Belgium

bLaboratory for the Analysis of Medicines (LAM), Department of Pharmacy, CIRM, University of Liege, Avenue Hippocrate 15, B36 Tour 4 +3, 4000 Liège, Belgium

\section{Table of contents}

SUPPLEMENTAL DATA .................................................................................................................... S2

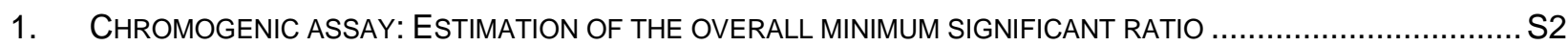

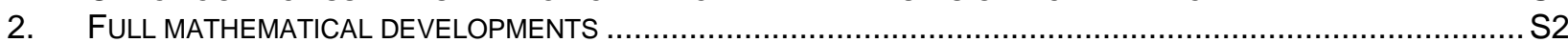

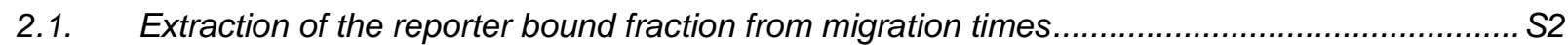

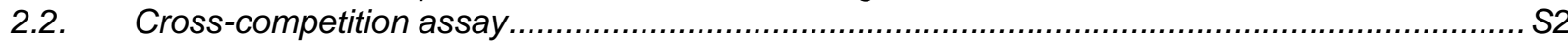

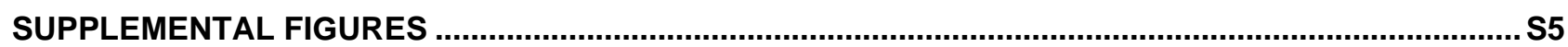

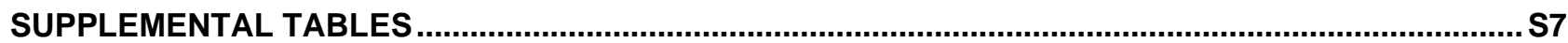

REFERENCES ............................................................................................................................... S12 


\section{SUPPLEMENTAL DATA}

\section{Chromogenic assay: Estimation of the overall minimum significant ratio}

The $\mathrm{IC}_{50}$ determination of PABZM was realized six times to calculate the overall minimum significant ratio (MSR). ${ }^{1}$ The $\mathrm{IC}_{50}$ recorded were $401.7 \mu \mathrm{M}, 480.3 \mu \mathrm{M}, 397.2 \mu \mathrm{M}, 458.9 \mu \mathrm{M}, 489.1 \mu \mathrm{M}$, and $456.6 \mu \mathrm{M}$. The calculated overall MSR from these values is equal to 1.3.

\section{Full mathematical developments}

\subsection{Extraction of the reporter bound fraction from migration times}

In ACE, reporter bound fraction can be calculated by Eq. S1.2,3 The complex mobility $\left(\mu_{c p l}\right)$ can be approximated by the macromolecule mobility $\left(\mu_{L}\right)$ when small ligands and big target, such as proteins, are used. ${ }^{3}$

$$
r=\frac{\left(\mu_{A, e f f}-\mu_{A}\right)}{\left(\mu_{c p l}-\mu_{A}\right)} \quad \text { where } \mu_{c p l}=\mu_{L}
$$

where $\mu_{A}$ is the mobility of the reporter, $\mu_{A, \text { eff }}$ the effective mobility of the reporter inside the target plug, $\mu_{c p l}$ the mobility of the complex E.R, and $\mu_{L}$ the mobility of the macromolecule.

Because a partial-filling system is used, the observed mobility of the reporter in the capillary partially filled with the target $\left(\mu_{o b s}\right)$ is not equal to the effective mobility inside the target plug $\left(\mu_{A \text {,eff }}\right)$. Indeed, a part of the reporter migration is in the target-free BGE. ${ }^{3}$ The $\mu_{A \text {,eff }}$ can be determined by Eq. S2, that was derived from the formula reported by Ansorge et al. ${ }^{4}$ considering that the electro-osmotic flow is equal to zero (due to PEO coating). ${ }^{3}$

$$
\mu_{A, e f f}=\frac{\mu_{o b s} \cdot \mu_{L}-\mu_{A} \cdot\left(x \cdot \mu_{o b s}+\mu_{L}\right)}{(1-x) \cdot \mu_{o b s}-\mu_{A}}
$$

Where $x$ is the fraction of the effective capillary length $\left(L_{\text {eff }}\right)$ that is filled with the target plug.

The Eq. S2 is incorporated into Eq. S1 and, after rearrangements, Eq. S3 is obtained.

$$
r=\frac{\left(\mu_{o b s}-\mu_{A}\right)}{(1-x) \cdot \mu_{o b s}-\mu_{A}}
$$

The electrophoretic mobility $\left(\mu\right.$, in $\left.10^{-9} \cdot \mathrm{m}^{2} \cdot \mathrm{V}^{-1} \cdot \mathrm{s}^{-1}\right)$ is linked to the migration time $\left(M_{t}\right)$ by Eq. $\mathrm{S} 4$.

$$
\mu=\frac{\left(L_{t o t} \cdot L_{e f f}\right)}{V \cdot M_{t}} \cdot 10^{9}
$$

where $L_{\text {tot }}$ and $L_{\text {eff }}$ are the total and effective length of the capillary in $\mathrm{m}, V$ is the voltage applied in $\mathrm{V}$, and $M_{t}$ is the migration time in sec.

Using Eq. S4, the Eq. S3 is transformed into the Eq. 5 to extract the reporter bound fraction directly from the migration time. Under the assumption that the $\mu_{c p l}$ is equal to $\mu_{L}$, the mobility of the target is not required for the calculation of the bound fraction (see Eq. 5).

$$
r=\frac{M_{t, R}-M_{t, P}}{(1-x) M_{t, R}-M_{t, P}}
$$

where $M_{t, R}$ is the migration time of the reporter without target plug, and $M_{t, P}$ is the migration of the reporter with the target plug.

\subsection{Cross-competition assay}

To evaluate the mutual exclusivity of two fragments, we designed the following equilibrium binding model (see Scheme S1). The macromolecule $(E)$ is allowed to form complex with the reporter $(R)$, the fragment $1\left(\mathrm{Fg}_{1}\right)$, the fragment $2\left(\mathrm{Fg}_{2}\right)$, or the two fragments, leading to E.R, E.Fg ${ }_{1}, E . F g_{2}$, or E. $F g_{1} . F_{2}$, respectively. It is assumed that R.Fg, E.R.Fg, and E.R.Fg are not formed, that no other type of interaction takes place, and that the binding stoichiometry is 1:1. 


$$
\begin{aligned}
& E \cdot R \underset{\kappa_{R}}{\leftrightarrows} E \underset{\kappa_{f g l}}{\leftrightarrows} E \cdot F g_{1} \\
& \downarrow \uparrow \kappa_{\mathrm{Fg} 2} \quad \downarrow \uparrow \alpha . K_{\mathrm{Fg} 2} \\
& \text { E. F } g_{2} \leftrightarrows E . F g_{1} \cdot F g_{2}
\end{aligned}
$$

\section{Scheme S1. Equilibria among enzyme species in the presence of the reporter and two fragments.}

The dissociation constants can be expressed as followed.

$$
K_{R}=\frac{[E][R]}{[E R]} \quad K_{F g 1}=\frac{[E]\left[F g_{1}\right]}{\left[E F g_{1}\right]} \quad K_{F g 2}=\frac{[E]\left[F g_{2}\right]}{\left[E F g_{2}\right]} \quad \alpha K_{F g 1}=\frac{\left[E F g_{2}\right]\left[F g_{1}\right]}{\left[E F g_{1} F g_{2}\right]}=\frac{[E]\left[F g_{2}\right]\left[F g_{1}\right]}{K_{F g 2}\left[E F g_{1} F g_{2}\right]}
$$

where $[E]$ is the macromolecule concentration, $[R]$ is the reporter concentration, $[E R]$ is the E.R concentration, $\left[\mathrm{Fg}_{1}\right]$ is the $\mathrm{Fg}_{1}$ concentration, $\left[\mathrm{EFg}{ }_{1}\right]$ is the $\mathrm{E} . \mathrm{Fg}_{1}$ concentration, $\left[\mathrm{Fg}_{2}\right]$ is the $\mathrm{Fg}_{2}$ concentration, $\left[E . F g_{2}\right]$ is the $E . F g_{2}$ concentration, $\left[E F g_{1} F g_{2}\right]$ is the $\mathrm{E} \mathrm{Fg}_{1}$. $\mathrm{Fg}_{2}$ concentration, $K_{\mathrm{R}}$ is the dissociation constant of the reporter, $K_{\mathrm{Fg} 1}$ is the dissociation constant of $\mathrm{Fg}_{1}, K_{\mathrm{Fg} 2}$ is the dissociation constant of $\mathrm{Fg}_{2}$, and $\alpha$ is the interaction constant between $\mathrm{Fg}_{1}$ and $\mathrm{Fg}_{2}$ in the $\mathrm{E}$. $\mathrm{Fg}_{1}$. $\mathrm{Fg}_{2}$ complex.

In Scheme S1, the total amount of macromolecule $\left(E_{0}\right)$ is described by Eq. S5.

$$
E_{0}=[E]+[E R]+\left[E F g_{1}\right]+\left[E F g_{2}\right]+\left[E F g_{1} F g_{2}\right]
$$

$[E],\left[E F g_{1}\right],\left[E F g_{2}\right]$, and $\left[E F g_{1} F_{2}\right]$ are replaced by $K_{R}, K_{\mathrm{Fg} 1}, K_{\mathrm{Fg} 2}$, and $\alpha K_{\mathrm{Fg} 1}$ (see above the expressions of the dissociation constants).

$$
E_{0}=\frac{K_{R}[E R]}{[R]}\left(1+\frac{\left[F g_{1}\right]}{K_{F g 1}}+\frac{\left[F g_{2}\right]}{K_{F g 2}}+\frac{\left[F g_{1}\right]\left[F g_{2}\right]}{\alpha K_{F g 1} K_{F g 2}}\right)+[E R]
$$

Eq. S6 is arranged into Eq. 6, an expression of the reporter bound fraction $r$. The reporter bound fraction is defined as the proportion of E.R complex relative to $E_{0}$.

$$
r=\frac{[E R]}{E_{0}}=\frac{[R]}{K_{R}\left(1+\frac{\left[F g_{1}\right]}{K_{F g 1}}+\frac{\left[F g_{2}\right]}{K_{F g 2}}+\frac{\left[F g_{1}\right] \cdot\left[F g_{2}\right]}{\alpha \cdot K_{F g 1} \cdot K_{F g 2}}\right)+[R]}
$$

The rearrangement of Eq. 6 into a linear function of $\left[\mathrm{Fg}_{1}\right]$ leads to Eq. 7.

$$
\left(\frac{1}{r}-1\right)=\frac{K_{R}}{[R]}\left(1+\frac{\left[F g_{1}\right]}{K_{F g 1}}+\frac{\left[F g_{2}\right]}{K_{F g 2}}+\frac{\left[F g_{1}\right] \cdot\left[F g_{2}\right]}{\alpha \cdot K_{F g 1} \cdot K_{F g 2}}\right)
$$

Eq. 7 indicates that a straight line will be obtained if $\left(\frac{1}{r}-1\right)$ is plotted against $\left[\mathrm{Fg}_{1}\right]$ at fixed $\left[\mathrm{Fg}_{2}\right]$.

The straight lines obtained with (Eq. 7) and without $\mathrm{Fg}_{2}$ (Eq. 4) cross at an $x$-axis and $y$-axis values described by Eq. S8 and S10, respectively. The $x$-coordinate of the intersection between Eq. 7 (with $\mathrm{Fg}_{2}$ ) and $\mathrm{Eq} .4$ (without $\mathrm{Fg}_{2}$ ) corresponds to the $x$-value when the $\mathrm{y}$ of $\mathrm{Eq} .4$ and 7 are equal (see Eq. S7).

$$
\frac{K_{R}}{[R]}\left(1+\frac{\left[F g_{1}\right]}{K_{F g 1}}\right)=\frac{K_{R}}{[R]}\left(1+\frac{\left[F g_{1}\right]}{K_{F g 1}}+\frac{\left[F g_{2}\right]}{K_{F g 2}}+\frac{\left[F g_{1}\right] \cdot\left[F g_{2}\right]}{\alpha \cdot K_{F g 1} \cdot K_{F g 2}}\right)
$$

After rearrangements:

$$
\left[F g_{1}\right]=-\alpha K_{F g 1}
$$

The $y$-coordinate of the intersection between $\mathrm{Eq} .7$ (with $\mathrm{Fg}_{2}$ ) and $\mathrm{Eq}$. 4 (without $\mathrm{Fg}_{2}$ ) can be determined using Eq. S8, that means replacing the $\left[\mathrm{Fg}_{1}\right]$ of Eq. 7 by $-\alpha K_{F g 1}$ (see Eq. S9).

$$
\left(\frac{1}{r}-1\right)=\frac{K_{R}}{[R]}\left(1+\frac{-\alpha K_{F g 1}}{K_{F g 1}}+\frac{\left[F g_{2}\right]}{K_{F g 2}}+\frac{-\alpha K_{F g 1} \cdot\left[F g_{2}\right]}{\alpha \cdot K_{F g 1} \cdot K_{F g 2}}\right)
$$


After rearrangements:

$$
\left(\frac{1}{r}-1\right)=\frac{-K_{R}}{[R]}(\alpha-1) \quad(\text { Eq.S10) }
$$




\section{SUPPLEMENTAL FIGURES}

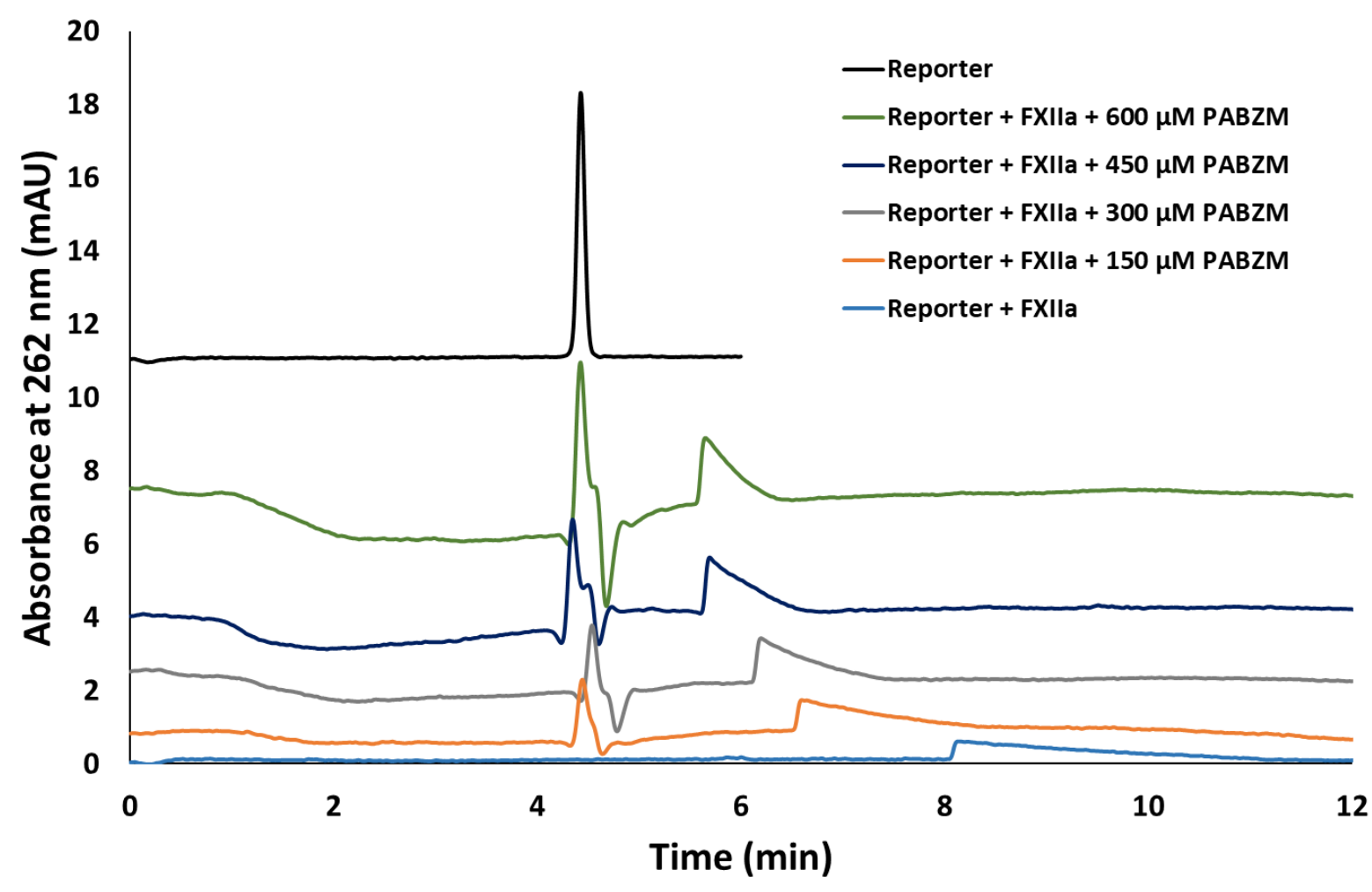

Figure S1. Impact of PABZM concentration on the reporter shift. The reporter $(10 \mu \mathrm{M})$ without the FXIla plug had a migration time of $4.4 \mathrm{~min}$ (black electropherogram). When the capillary is filled with $5.6 \mathrm{~cm}$ of FXIla $(15 \mu \mathrm{M})$, the peak shifted and experienced electromigration distortion (EMD). Fitting the distorted peaks to the Haarhoof-Van der Linde function extracted the corrected migration times. In the neat BGE, the shift was $6.8 \mathrm{~min}$ (light blue electropherogram). When increasing concentrations of PABZM were added to the BGE, the reporter's shift was reduced (orange, grey, dark blue, and green electropherograms). In these electropherograms, the perturbations arising around 4.5 min correspond to the injection zone. Indeed, the addition of PABZM in the BGE creates a system zone at its migration time. The reporter injection in the capillary causes a disturbance in the originally uniform composition of the BGE.

BGE: background electrolyte, FXIla: factor XIla, PABZM: p-aminobenzamidine. 


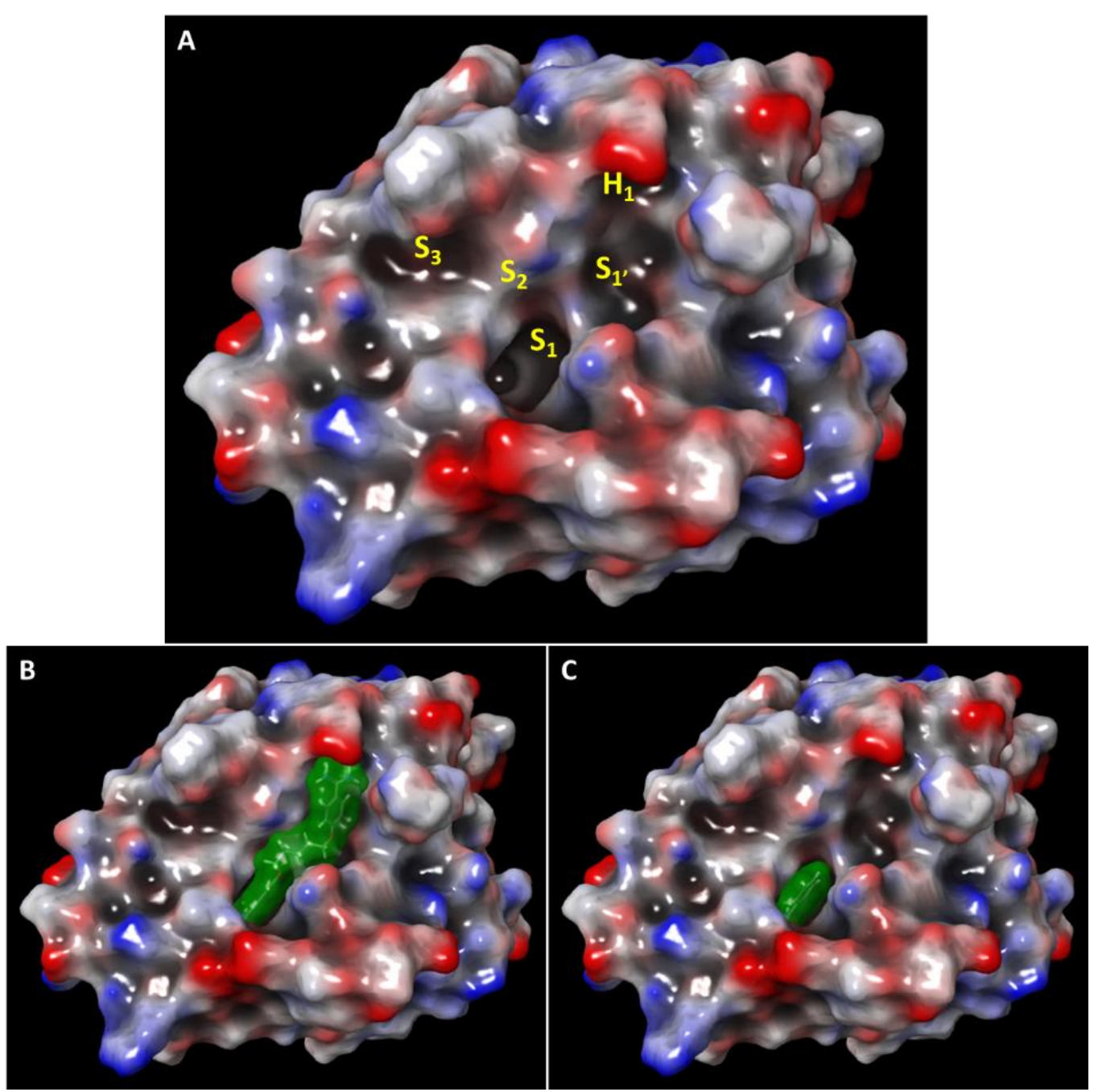

Figure S2. Representations of the $\beta$-FXIla active site (PDB: 6B74). (A) Localization of the specificity pockets, $(B)$ docking pose of pentamidine, and $(C)$ binding site of benzamidine (PDB: 6B74). 


\section{SUPPLEMENTAL TABLES}

Table S1. Tested background electrolytes (BGE) for buffer capacity enhancement. The initial BGE showed an insufficient buffer capacity as depicted by the increase of $\mathrm{pH}$ after addition of a mixture of $3 \mathrm{mM}$ basic fragments. The Alternative 1 was selected because this buffer supported the addition of $3 \mathrm{mM}$ basic fragments and generated a stable current with repeatable electromigration of the reporter. AUC: area under the curve, BGE: background electrolytes, $M_{t, R}$ : migration time of the reporter without the FXIla plug.

\begin{tabular}{|c|c|c|c|c|c|c|c|c|c|}
\hline \multirow[t]{2}{*}{$\begin{array}{l}\text { Composition } \\
\text { of the BGE }\end{array}$} & \multirow{2}{*}{$\begin{array}{c}\mathbf{p H} \\
\text { at } \\
22 \pm 1.5^{\circ} \mathrm{C} \\
(\mathrm{n}=1)\end{array}$} & \multirow{2}{*}{$\begin{array}{c}\text { pH with } 3 \\
\text { mM basic } \\
\text { fragments }^{\mathrm{a}} \\
\text { at } \\
22 \pm 1.5^{\circ} \mathrm{C} \\
(\mathrm{n}=1)\end{array}$} & \multirow{2}{*}{$\begin{array}{c}\text { Current } \\
\text { at - 3kV } \\
\pm S_{D} \\
(\mu A) \\
(n=3)\end{array}$} & \multicolumn{2}{|c|}{$\begin{array}{c}\boldsymbol{M}_{t, R}(\min ) \\
(\mathrm{n}=3)\end{array}$} & \multicolumn{2}{|c|}{$\begin{array}{l}\text { AUC } \\
(n=3)\end{array}$} & \multirow[t]{2}{*}{$\begin{array}{c}\text { lonic } \\
\text { strength }^{b} \\
\text { (M) }\end{array}$} & \multirow[t]{2}{*}{$\begin{array}{c}\text { Buffer } \\
\text { capacity } \\
(\mathrm{mM})\end{array}$} \\
\hline & & & & $\begin{array}{l}\text { Mean } \\
\pm S_{D}\end{array}$ & $\begin{array}{l}\text { RSD } \\
(\%)\end{array}$ & $\begin{array}{l}\text { Mean } \\
\pm S_{D}\end{array}$ & $\begin{array}{l}\text { RSD } \\
(\%)\end{array}$ & & \\
\hline Initial BGEc & 7.38 & 7.58 & $\begin{array}{r}54.5 \\
\pm 0.1\end{array}$ & $\begin{array}{c}4.44 \\
\pm 0.01\end{array}$ & 0.22 & $\begin{array}{r}35.6 \\
\pm 0.2\end{array}$ & 0.65 & 0.13 & 6 \\
\hline Alternative $1^{\mathrm{d}}$ & 7.38 & 7.43 & $\begin{array}{r}48.6 \\
\pm 0.1\end{array}$ & $\begin{array}{c}4.39 \\
\pm 0.03\end{array}$ & 0.66 & $\begin{array}{l}34.6 \\
\pm 0.8\end{array}$ & 2.17 & 0.13 & 20 \\
\hline Alternative $2^{\mathrm{e}}$ & 7.38 & 7.42 & $\begin{array}{r}51.7 \\
\pm 0.1\end{array}$ & $\begin{array}{c}4.28 \\
\pm 0.77\end{array}$ & 17.9 & $\begin{array}{r}32.6 \\
\pm 6.8\end{array}$ & 21.0 & 0.15 & 42 \\
\hline
\end{tabular}

\footnotetext{
a The $3 \mathrm{mM}$ basic fragments addition corresponds to the addition of compounds 1, 2, 3, 4, and 5 (600 $\mu \mathrm{M}$ each).
}

b These properties were calculated by PeakMaster $6.0 f 8$ program. ${ }^{5}$

All the BGE were prepared by 2.5 -fold diluting the FXIla storage buffer ( $4 \mathrm{mM}$ Acetate- $\mathrm{Na}, 150 \mathrm{mM} \mathrm{NaCl}$, adjusted at pH 5.3 with $0.1 \mathrm{M} \mathrm{H}_{3} \mathrm{PO}_{4}$ ) with a Tris-Hepes buffer.

${ }^{c}$ The Tris-Hepes buffer of the initial BGE consists of $10 \mathrm{mM}$ Tris-HCl, $10 \mathrm{mM}$ Hepes-Na, $100 \mathrm{mM} \mathrm{NaCl}, 167 \mu \mathrm{M}$ EDTA, adjusted at $\mathrm{pH} 7.5$ with $0.1 \mathrm{M} \mathrm{H}_{3} \mathrm{PO}_{4}$.

${ }^{d}$ The Tris-Hepes buffer of Alternative 1 consists of $35 \mathrm{mM}$ Tris- $\mathrm{HCl}, 35 \mathrm{mM}$ Hepes-Na, $35 \mathrm{mM} \mathrm{NaCl}, 167 \mu \mathrm{M}$ EDTA, adjusted at $\mathrm{pH} 7.4$ with $0.1 \mathrm{M} \mathrm{H}_{3} \mathrm{PO}_{4}$.

e The Tris-Hepes buffer of Alternative 2 consists of $75 \mathrm{mM}$ Tris- $\mathrm{HCl}, 75 \mathrm{mM}$ Hepes-Na, $167 \mu \mathrm{M}$ EDTA, adjusted at pH 7.4 with $0.1 \mathrm{M} \mathrm{H}_{3} \mathrm{PO}_{4}$. 


\section{Reference \\ Compounds \\ Structure \\ Chromogenic \\ ACE assay at assay at $1 \mathrm{mM} \quad 600 \mu \mathrm{M}$ (shift \\ (inhibition - \%) inhibition - \%) at $\mathrm{pH} 7.4$}

Diminazene


Table S3. Evaluation of the mixture effect on PhGu, BZM, and NAMFrag66.

\begin{tabular}{|c|c|c|c|c|c|c|c|}
\hline & \multirow{2}{*}{$\begin{array}{c}\text { Current } \pm \\
S_{D} \\
\text { at }-3 k V \\
(\mu A) \\
(n=3)\end{array}$} & \multicolumn{2}{|c|}{$\begin{array}{l}\text { Mt of the reporter } \\
\qquad \begin{array}{c}(\min ) \\
(\mathrm{n}=3)\end{array}\end{array}$} & \multicolumn{2}{|c|}{$\begin{array}{l}\text { Mt of the reporter + } \\
\text { FXIla (min) } \\
(n=3)\end{array}$} & \multirow{2}{*}{$\begin{array}{l}\text { Shift } \\
\text { (min) }\end{array}$} & \multirow{2}{*}{$\begin{array}{c}\text { Shift } \\
\text { inhibition } \\
(\%) \\
\pm S_{D}\end{array}$} \\
\hline & & Mean $\pm S_{D}$ & $\begin{array}{l}\text { RSD } \\
(\%)\end{array}$ & Mean $\pm S_{D}$ & $\begin{array}{l}\text { RSD } \\
(\%)\end{array}$ & & \\
\hline BGE control & $47.3 \pm 0.1$ & $4.41 \pm 0.02$ & 0.4 & $11.1 \pm 0.04$ & 0.3 & 6.7 & $0 \pm 0.8$ \\
\hline PhGu & $47.6 \pm 0.3$ & $4.34 \pm 0.01$ & 0.3 & $10.7 \pm 0.11$ & 1.0 & 6.4 & $4.6 \pm 1.8$ \\
\hline $\begin{array}{c}\text { PhGu } \\
+\operatorname{mix} 1\end{array}$ & $48.2 \pm 0.1$ & $4.42 \pm 0.01$ & 0.3 & $10.8 \pm 0.12$ & 1.1 & 6.4 & $4.8 \pm 1.9$ \\
\hline $\begin{array}{c}\text { PhGu } \\
+\operatorname{mix} 2\end{array}$ & $48.2 \pm 0.1$ & $4.24 \pm 0.06$ & 1.4 & $10.7 \pm 0.14$ & 1.3 & 6.4 & $5.3 \pm 2.6$ \\
\hline BZM & $47.6 \pm 0.1$ & $4.45 \pm 0.02$ & 0.4 & $8.72 \pm 0.05$ & 0.6 & 4.3 & $36.1 \pm 0.9$ \\
\hline $\begin{array}{c}\text { BZM } \\
+\operatorname{mix} 1\end{array}$ & $48.1 \pm 0.1$ & $4.70 \pm 0.03$ & 0.6 & $8.71 \pm 0.07$ & 0.8 & 4.0 & $40.1 \pm 1.2$ \\
\hline $\begin{array}{c}\text { BZM } \\
+\operatorname{mix} 3\end{array}$ & $47.8 \pm 0.3$ & $4.15 \pm 0.03$ & 0.8 & $7.96 \pm 0.04$ & 0.5 & 3.8 & $44.0 \pm 1.0$ \\
\hline NAMFrag66 & $47.4 \pm 0.1$ & $4.49 \pm 0.02$ & 0.3 & $7.38 \pm 0.06$ & 0.8 & 2.9 & $56.8 \pm 1.0$ \\
\hline $\begin{array}{l}\text { NAMFrag66 } \\
+\operatorname{mix} 1\end{array}$ & $47.8 \pm 0.1$ & $4.71 \pm 0.01$ & 0.2 & $7.48 \pm 0.07$ & 0.9 & 2.8 & $58.6 \pm 1.1$ \\
\hline $\begin{array}{c}\text { NAMFrag66 } \\
+\operatorname{mix} 4\end{array}$ & $48.4 \pm 0.1$ & $4.19 \pm 0.01$ & 0.1 & $6.94 \pm 0.04$ & 0.5 & 2.8 & $59.5 \pm 0.7$ \\
\hline $\begin{array}{c}\text { BZM + } \\
\text { NAMFrag66 }\end{array}$ & $48.1 \pm 0.1$ & $4.13 \pm 0.01$ & 0.1 & $6.40 \pm 0.06$ & 0.9 & 2.3 & $66.5 \pm 0.9$ \\
\hline $\begin{array}{c}\text { BZM + } \\
\text { NAMFrag66 } \\
+\operatorname{mix} 5\end{array}$ & $47.9 \pm 0.1$ & $4.35 \pm 0.02$ & 0.5 & $6.64 \pm 0.07$ & 1.0 & 2.3 & $66.4 \pm 1.2$ \\
\hline
\end{tabular}


Table S4. Non-active fragments. Zw.: zwitterionic.

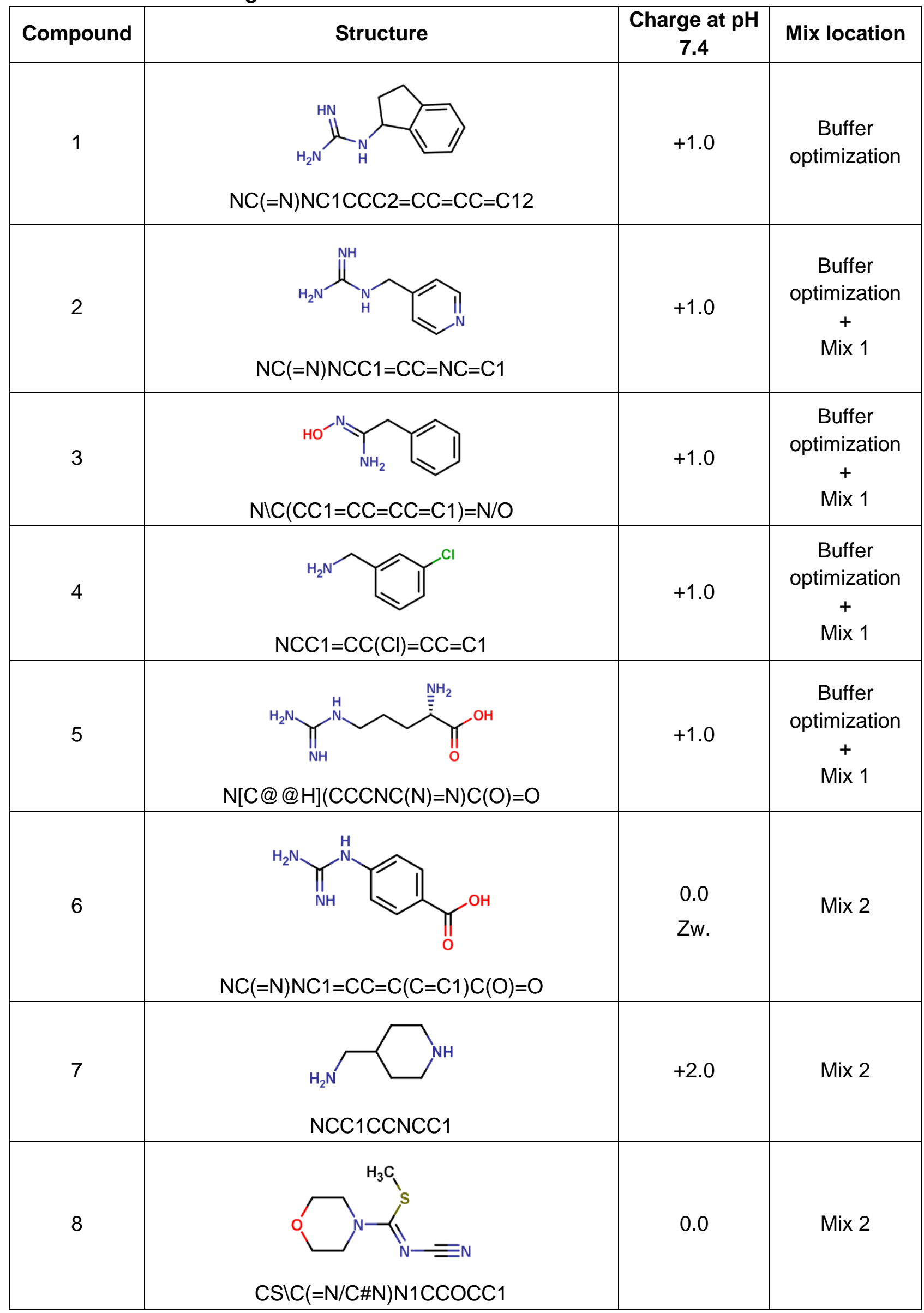




\begin{tabular}{|c|c|c|c|}
\hline 9 & $\operatorname{ccc} 1(\mathrm{C}(=\mathrm{O}) \mathrm{NC}(=\mathrm{O}) \mathrm{NC} 1=\mathrm{O}) \mathrm{C} 1=\mathrm{CC}=\mathrm{CC}=\mathrm{C} 1$ & -0.6 & Mix 2 \\
\hline 10 & $\mathrm{NC}(=\mathrm{O}) \mathrm{C} 1 \operatorname{cccN}(\mathrm{C} 1) \mathrm{C}(\mathrm{N})=\mathrm{O}$ & 0.0 & Mix 3 \\
\hline 11 & $\operatorname{ccoc}(=0) C 1=C(O) C=C(C) S 1$ & -1.0 & Mix 3 \\
\hline 12 & $\operatorname{coc} 1=\operatorname{cc}(\mathrm{OCC}(\mathrm{O})=\mathrm{O})=\mathrm{CC}=\mathrm{C} 1 \mathrm{Cl}$ & -1.0 & Mix 3 \\
\hline 13 & $\mathrm{NC}(=\mathrm{O})[\mathrm{C} @ \mathrm{H}] 1 \mathrm{CCCN} 1$ & +1.0 & $\operatorname{Mix} 3$ \\
\hline 14 & $\mathrm{OC}(=\mathrm{O}) \mathrm{CC} 1=\mathrm{C}(\mathrm{Cl}) \mathrm{C}=\mathrm{CC}(\mathrm{Cl})=\mathrm{C} 1$ & -1.0 & Mix 4 \\
\hline 15 & $\mathrm{NCC} 1=\mathrm{CC} 2=\mathrm{C}(\mathrm{CNC} 2) \mathrm{C}=\mathrm{C} 1$ & +1.9 & $\operatorname{Mix} 4$ \\
\hline
\end{tabular}




\begin{tabular}{|c|c|c|c|}
\hline 16 & $\mathrm{~N}[\mathrm{C} @ \mathrm{H}] 1 \mathrm{CC}[\mathrm{C} @ @ \mathrm{H}](\mathrm{N}) \mathrm{CC} 1|01: 1,4|$ & +2.0 & Mix 4 \\
\hline 17 & $\mathrm{CC}(=\mathrm{O}) \mathrm{NCC} 1=\mathrm{CC}=\mathrm{C}(\mathrm{F}) \mathrm{C}=\mathrm{C} 1$ & 0.0 & Mix 4 \\
\hline 18 & $\mathrm{C}[\mathrm{C} @ @ \mathrm{H}] \mathrm{CCN}[\mathrm{C} @ \mathrm{H}](\mathrm{C} 1) \mathrm{C}(\mathrm{O})=\mathrm{O}$ & $\begin{array}{l}0.0 \\
Z w .\end{array}$ & Mix 5 \\
\hline 19 & $\mathrm{CC}(=\mathrm{O}) \mathrm{NC} 1=\mathrm{C}(\mathrm{C}=\mathrm{C}(\mathrm{C}=\mathrm{C} 1) \mathrm{N} 1 \mathrm{Ccoc} 1) \mathrm{C}(\mathrm{O})=\mathrm{O}$ & -1.0 & Mix 5 \\
\hline 20 & OC(=O)[C@@H]1CCCCN1 & $\begin{array}{l}0.0 \\
Z w\end{array}$ & Mix 5 \\
\hline
\end{tabular}

\section{REFERENCES}

(1) Haas, J. V.; Eastwood, B. J.; Iversen, P. W.; Devanarayan, V.; Weidner, J. R. Minimum Significant Ratio - A Statistic to Assess Assay Variability; 2004.

(2) Colton, I. J.; Carbeck, J. D.; Rao, J.; Whitesides, G. M. Affinity Capillary Electrophoresis: A Physical-Organic Tool for Studying Interactions in Biomolecular Recognition. Electrophoresis 1998, 19 (3), 367-382. https://doi.org/10.1002/elps.1150190303.

(3) Davoine, C.; Fillet, M.; Pochet, L. Capillary Electrophoresis as a Fragment Screening Tool to Cross-Validate Hits from Chromogenic Assay: Application to FXIla. Talanta 2021, 226, 122163. https://doi.org/10.1016/j.talanta.2021.122163.

(4) Ansorge, M.; Dubský, P.; Ušelová, K. Into the Theory of the Partial-Filling Affinity Capillary Electrophoresis and the Determination of Apparent Stability Constants of Analyte-Ligand Complexes. Electrophoresis 2018, 39 (5-6), 742-751. https://doi.org/10.1002/elps.201700385.

(5) Jaroš, M.; Hruška, V.; Štědrý, M.; Zusková, I.; Gaš, B. Eigenmobilities in Background Electrolytes for Capillary Zone Electrophoresis: IV. Computer Program PeakMaster. Electrophoresis 2004, 25 (1819), 3080-3085. https://doi.org/10.1002/elps.200405982. 